OPEN ACCESS

Edited by:

Tara Ratnam,

Independent Researcher, Karnataka,

India

Reviewed by:

Ana Luiza Bustamante Smolka,

Campinas State University, Brazil

Peter Eland Jones,

Sheffield Hallam University,

United Kingdom

*Correspondence:

Anna Stetsenko

astetsenko@gc.cuny.edu

Specialty section:

This article was submitted to

Teacher Education,

a section of the journal

Frontiers in Education

Received: 20 August 2019

Accepted: 28 November 2019

Published: 17 December 2019

Citation:

Stetsenko A (2019)

Radical-Transformative Agency: Continuities and Contrasts With

Relational Agency and Implications for Education. Front. Educ. 4:148. doi: 10.3389/feduc.2019.00148

\section{Radical-Transformative Agency: Continuities and Contrasts With Relational Agency and Implications for Education}

\author{
Anna Stetsenko* \\ The Graduate Center, The City University of New York, New York, NY, United States
}

The recent scholarship on agency is mostly centered around a relational (also known as situative, contextual, distributed, and ecological) approach that draws attention to agency being situated in context and contingent on sociocultural interactivities and contextual dynamics. My central argument is that there is a residue of passivity in these conceptions. Illustrative of this are the works by Bietsa and colleagues which I analyse to reveal conceptual flaws that need to be addressed. To overcome these flaws, it is important to reconstrue no less than the very basic premises about human development, context/reality, and teaching-learning to foreground a more radical view of agency conducive to combatting inequalities and injustices in education. In the alternative approach, termed the Transformative Activist Stance, human development is posited to be not only fully immersed in the world and its contextual dynamics but, more critically, realized by each individual's agentive contributions to communal practices, whereby these practices are changed as a whole every time a person acts as an active member of community. The emphasis is on the nexus of people changing the world and being changed in this very process of them changing the world-as two poles of one and the same, bi-directional and recursive, co-constitution of people and the world in a simultaneous self- and world-realization. People never merely react or respond to what exists but agentively act in co-realizing both the world and themselves. Agency in this account is accorded with a formative role in the processes of co-realizing both human development, the overall sociohistorical dynamics, and the world itself. Importantly, agency development is contingent on access to cultural tools that need to be provided by society and agentively taken up by each individual. There are starkly contrasting sociopolitical conjectures and implications geared to the issues of inequalities and injustices in education. The notion of a radical-transformative agency is deployed in order to expose and overcome ideologies of passive adaptation to, and acquiescence with, the existing order of things and the world as it presumably "is."

Keywords: sociopolitical, ecological, activism, Biesta, Vygotsky, cultural-historical activity theory 


\section{INTRODUCTION}

Agency is a topic that has been, for decades, vigorously contested and debated across social sciences including in psychology and education (for a recent review of the field, see Eteläpelto et al., 2013). It has recently made inroads into sociocultural and cultural-historical activity theories and at this point, there is a surge of interest in how to understand agency within these perspectives (see e.g., Edwards, 2005; Sannino et al., 2016; Kumpulainen et al., 2018). It is great to see the rallying of interest and efforts to tackle this important issue, the relevance of which is especially obvious today, in the context of a global sociopolitical and economic-structural crisis of the late-stage predatory capitalism and associated inequalities and injustices in education. In many works, dominant continues to be the relational (also known as situative, contextual, distributed, and ecological) approach which draws attention to agency being situated in context and contingent on sociocultural interactivities and dynamics. This is in line with what is considered to be the most important achievement of recent years-the focus on learning and human development being embedded in social contexts and practices. Indeed, for example, Sawyer states in his introduction to The Cambridge Handbook of the Learning Sciences (Sawyer, 2007) that the most influential achievement

by a group of interrelated approaches including the sociocultural, situative, and distributed cognition approaches... [consisted in] the observation that all intelligent behavior was realized in a complex environment filled with tools and machines, but also a deeply social environment with collaborators and partners. ... This research revealed that outside of formal schooling, almost all learning occurs in a complex social environment, and learning is hard to understand if one thinks of it as a mental process occurring within the head of an isolated learner. (p. 9; emphasis added)

This group of interrelated approaches indeed provides many insights into the nature of human development and learning including agency. However, in my works through the past years (e.g., Stetsenko and Arievitch, 1997, 2004; Stetsenko, 1999, 2005, 2008, 2012), I have attempted to draw attention to the need to overcome significant limitations within relational approaches to agency that today dominate its discussions. My central argument has been that there is a residue of passivity in all major conceptions of development and agency and that in order to overcome this residue, it is important to reconstrue no less than the very basic premises about human development. These premises include ideas about how we are and how we can be in the world, what constitutes humanness, what is reality and, most critically, what could be a humane and just society in which this humanness is possible, along and together with sets of closely and non-coincidentally related values and commitments. What is needed, in other worlds, in order to address agency and its role in human development, is a philosophically grounded revision, indeed an overhaul, of the major assumptions about human development, mind, the nature of knowledge and, ultimately, reality itself-away from assumptions of passivity, accommodation, quietism, and adaptation to the status quo.

In this paper, I present the core outlines of an approach to agency that is based in a transformative worldview-an overall framework to conceptualize human development as a process that is relational yet also extending beyond relationality with its ethos of passive adaptation to what exists (for an extended discussion, see Stetsenko, 2016). In the transformative worldview, reality is reconceived as that which is being constantly transformed and realized (literally made real) by people themselves-and, importantly, by people not as isolated, autonomous entities but as agentive actors or active agents of social practices. At the same time, human development is posited to be not only fully immersed in collaborative practices but, more to the point, co-constituted by each individual's active contributions to these practices, whereby the dynamics of what exists is changed as a whole every time a person acts. The emphasis is thus on the nexus of people changing the world and being changed in this very process of them changing the world-as two poles of one and the same, bi-directional, and recursive co-constitution of people and the world in a process of a simultaneous self- and world-realization. This approach implies that people never merely react, nor respond, to what exists but agentively act in co-creating both the world and themselves beyond "the givenness" of the present. Agency in this account is accorded with a central, formative (or constitutive) role in the processes of human development, the overall sociohistorical dynamics, and the very materiality of the world. In addition and quite critically, the development of agency is contingent on access to cultural tools and resources that afford it, an access that needs to be provided by society and also agentively taken up by each individual. Therefore, discussions of agency are immediately related to how societies afford of stifle agency and thus, to fundamental issues of social equality and justice.

One critical point to be articulated in this paper is that human beings cannot be considered as existing separately and autonomously not only from other people but also from realityas if they could merely react to what is simply "out there," somehow given in advance and existing in the form of a presumably fixed and stable status quo, for us to merely answer to the challenges and problems that the world somehow posits (or presents) for us. This point is not explicitly addressed in relational and ecological accounts of agency which typically stay (implicitly or explicitly) with the premise that people merely react to the world. My proposal is that it is time to move past ecological and relational approaches in their emphasis on reactive/responsive modes of agency-while preserving their important insightsand toward more explicitly political and activist accounts of agency that challenge the status quo and that are urgently needed today in our world in the state of a profound crisis and turmoil. Along the way, it is critical to consider how we are not merely "in" the world but are ourselves the world because we are directly implicated in its dynamics as its co-creators. This seemingly simple premise is actually quite generative and will be explored in its implications for education. This approach is contrastively illustrated by a careful analysis of the ecological approach to agency offered in influential works by Gert Biesta and his colleagues to reveal the gaps that need to be addressed. 
The step needed today, in my view, is to dialectically expand relationality through the notion that human development is an activist project that is not only imbued with dialogism, ethics, and interrelatedness but also, and more critically, is grounded in collaborative, purposeful, and answerable contributions (deeds) by agentive actors of social practices and thus, ineluctably colored by visions of and commitments to particular projects of social transformation.

\section{THE RELATIONAL-ECOLOGICAL APPROACH TO AGENCY: WORKS BY GERT BIESTA AND COLLEAGUES}

One line of works on agency that is clearly relational and directly engaged with issues of education, deserves some scrutiny for its interesting and important developments as well as its gaps, namely, the prolific writings by Gert Biesta and his colleagues (e.g., Biesta and Tedder, 2006, 2007; Biesta et al., 2015; Priestley et al., 2015). This line of work argues against the separation of humans from their world and instead, pays attention to the role of interactivity (interaction and relation) in the genesis of agency and insists on agency being about not something that people have but something that they do. In this approach, "rather than seeing agency as residing in individuals as a property or capacity, the ecological view of agency sees agency as an emergent phenomenon of the ecological conditions through which it is enacted" (Priestley et al., 2015, p. 22). That is, agency is taken to denote "a 'quality' of the engagement of actors with temporal-relational contexts-for-action, not a quality of the actors themselves" (Biesta and Tedder, 2007, p. 136). Therefore, "this concept of agency highlights that actors always act by means of their environment rather than simply in an environment" (Biesta and Tedder, 2007, p. 137). Thus, "the achievement of agency always results from the interplay of individual efforts, available resources and contextual and structural 'factors' as they come together in particular and, in a sense, always unique situations" (Biesta and Tedder, 2007).

While agreeing, in general, with these points and their overall orientation away from the focus on isolated individuals, especially with it placing emphasis on the interactive and situated character of agency, I also think it is important to note the following. In this account the core notion is that agency is about the capacity of actors to shape their responses (responsiveness) to problematic situations that they are presented with in their lives and contexts. In this emphasis, these authors build upon the influential paper by Emirbayer and Mische (1998), where agency is related to

the temporally constructed engagement by actors of different structural environments - the temporal-relational contexts of action - which, through the interplay of habit, imagination, and judgement, both reproduces and transforms those structures in interactive response to the problems posed by changing historical situations. (p. 970; emphasis added)

In an agreement with this position, Biesta and Tedder (2007) associate agency, right from the start and very centrally throughout their work, with responsiveness to the world while locating agency "in the ability to shape our responsiveness to ...contexts" (p. 133; emphasis added). While also focusing on "the dynamic interplay of iterative, projective and practicalevaluative dimensions, which takes into consideration how this interplay varies within different contexts-for-action" (Biesta and Tedder, 2007), the authors accord responsiveness to the world with a truly central, formative role in conceptualizing agency. In this vein, Biesta and Tedder specifically emphasize that "the achievement of agency is inextricably linked with the ways in which people are 'in control' of their responses" (2007, p. 138; emphasis added). In further explicating their position (Biesta and Tedder, 2007), the authors draw attention to the point that Emirbayer and Mische "do not simply equate agency with the ways in which we respond to events in our life but ... highlight the importance of 'the capacity of actors to critically shape their own responsiveness to problematic situations' [(Emirbayer and Mische, 1998), p. 971, emph. added (by Biesta and Tedder)].”

The responsiveness to context as an ability to respond to the challenges it poses is foregrounded throughout this whole approach, with the authors bringing it up again and again. This is the case when they are writing about one of their participant's "responsiveness to the particular problems" (Biesta and Tedder, 2007 , p. 143; emphasis added), her being "responsive to the opportunities that have arisen for her during her life" so that she

\footnotetext{
displays a level of control over the ways she can respond to the problematic situations she encounters. Marie finds herself in situations where new opportunities arise and responds intuitively and such intuition is firmly grounded in her earlier experiences though always constrained within the context of her material and cultural capital (Biesta and Tedder, 2007, pp. 143-144; emphasis added).
}

This and the other participant that the authors write about are understood to "respond to the situations they encounter in their life" (Biesta and Tedder, 2007, p. 144; emphasis added) and, in addition, "their ability to shape their own responsiveness to the problems and issues they encounter in their lives" is also noted (Biesta and Tedder, 2007; emphasis added). The authors state that " $\mathrm{i}$ ] n both cases there is evidence that they [the two participants] are aware and, to a certain extent, in control of the ways in which they respond to and deal with the issues and problems they encounter" (Biesta and Tedder, 2007, emphasis added). The same emphasis is evident in the authors further arguing "that agency is not simply concerned with the ways in which we engage with our contexts-for-action but rather has to do with the capacity to shape our responsiveness to the situations we encounter in our lives" (Biesta and Tedder, 2007, p. 146; emphasis added). The same connotation comes up yet again in the formulation that "individual actors can reframe the composition of their agentic orientations so as to change their responsiveness to particular problematic situations" (Biesta and Tedder, 2007, p. 147; emphasis added).

Finally, in summing up their approach, Biesta and Tedder (2007) connect their position on agency to a larger structural process that they see as being currently focal in our societies, 
namely that "under current societal conditions, individuals are increasingly 'forced' to take control of their lives. The approach presented in this paper at least indicates one kind of learning that could support individuals' attempts to achieve agency under such conditions" (Biesta and Tedder, 2007, p. 147; emphasis added). This larger framing reveals important features of the authors' overall approach, including in its political-ideological dimensions. I will return to this point after first addressing the core assumptions of Biesta and his colleagues' account of agency.

Note how the formulation of agency as a capacity to shape our responses to problematic situations immediately, though tacitly, erects a wall between the person and the world, all the formulations in favor of ecological situativity of agency notwithstanding. To see this requires a close reading of the authors' argumentation and the extended quotes above are meant to serve this purpose. Looking closely at these formulations, one can note that when agency is posited to be about shaping responses to problematic situations, then it inevitably follows that the world first presents problematic situations and only then, in "the second act" that follows, people shape their responses to these situations.

Indeed, a response is quite obviously always something that follows previous events or inputs-it is a reaction to antecedent conditions, that is, a reaction to something that precedes it. Given this, if we operate with the notion of response and responsivity, then what the world (or context) presents to us-as problems and challenges, or as opportunities and chances etc.-is inevitably understood to be temporarily and conceptually separated, as antecedent conditions, from our responses. That is, in this case, our responses merely follow with what is first given (or presented to us) and our role is only to act after the fact of being presented with the situation. Ironically, one can hear echoes of the old and tried behavioristic notions of the infamous "stimulus-response" formula in this account.

It is fairly certain that Biesta and his colleagues would vehemently reject any allegiance with behaviorism and my claim is not that they fall for all things behavioristic. After all, behaviorism was (and continues to be, as it is still alive and well today) a programmatic attempt to reduce all human behavior to essentially mechanistic, algebraic interactions between stimuli and responses. This influential school developed its own exotic language to describe mechanistically understood interactions such as reinforcement, habit strength, inhibition, behavioral oscillation, response evocation, response tendencies, and inhibitions. Behaviorism is infamous for its avowedly mechanistic, anti-mentalist, and anti-subjective orientation that reduces all diversity of human life to forms and formulas described as empirical laws. Its main classic assumption was (as expressed by Hull, 1943, p. v) that "all behavior, individual and social, moral and immoral, normal and psychopathic, is generated from the same primary laws; that the differences in the objective behavioral manifestations are due to the differing conditions under which habits are set up and function" (emphasis added). None of these specific assumptions apply to the works of Biesta and his colleagues.
Yet in my view, certain echoes of behaviorism, related to the posited overall passivity of human beings, are tacitly reverberating in Biesta's and many (if not all) other relational and ecological approaches, including even in Marxism (for details, see Stetsenko, 2019b). This is by virtue of these approaches understanding the world as something that is "given" and as such, as posing problems to (for) us, irrespective of our own participation in and contribution to how the world is and what it can or cannot pose or present to us, in the first place! It is not that the assumption about such participation and contribution is explicitly refuted. Yet the problem with relational approaches, to be very specific, is that they do posit (more or less explicitly) that the world can present something to us, for example as a problematic situation, without and outside of, or prior to, our engagement with it. This is about presenting things to us as a process which is, temporally and substantively, relatively independent from (albeit somehow coordinated with) what we ourselves are doing and struggling for. In this take on agency and humans' place in the world that serves as the grounding for conceptualizing agency, the process of the world presenting problematic situations to humans apparently happens by itself, irrespective of who it is for whom the situation might be or not be problematic, of who the person is, and what this person is doing, struggling against, hoping for, and aspiring to.

Similarly, if the assumption is that individuals attempt to achieve agency under given conditions (as mentioned several times in Biesta and Tedder, 2007), then the world and its conditions are presumed to exist "as is," as something that is given, established, and fixed-a static realm that is above (and beyond) human beings themselves since we act under its conditions. This is again indicative of a position that people are relatively passive at least as regards our limited scope of agency and ability to act, since we are presumably not involved in how the conditions "under" which we act are set in place before we ourselves get a chance to act on them.

It is not my intent to undermine the work of Biesta and colleagues who are, to reiterate, quite prolific and also probing deeply into many important issues and problems in education and beyond. Precisely because their work is strong and influential, I am drawing attention to the conceptual flaws in their approach specifically to agency in order to get across how complex and non-trivial the task to theorize agency, in ways that do not separate people from the world and thus portray them as ultimately inevitably powerless, actually is (for further elaboration, see Stetsenko, in press). It is one thing to take up notions such as about agency being situated and ecological, about its inherent interactivity, its embedding in context and other similar (and quite important) points, yet it is quite another thing to fully draw implications and groundings for an approach that resolutely breaks with all the tacit passive, mechanistic (including behavioristic) assumptions, biases, and deeply ingrained premises that still posit human beings as essentially autonomous, isolated, and separated from the worldas is the case under the overall view that people merely react to the world.

On a related point, I believe it is no coincidence that Biesta and his colleagues' approach to agency, although couched in 
politically and ethically neutral terms, is actually associated with a particular type of politics and ideology. As mentioned at the beginning of this section, Biesta and Tedder $(2006,2007)$ connect their position on agency to a larger structural process that they see as being currently focal in our societies, pointing out that "under current societal conditions, individuals are increasingly 'forced' to take control of their lives." (p. 147). What kind of societal conditions force individuals to take control of their lives? Biesta and Tedder (2007) address this question quite briefly in referencing, among others, Anthony Giddens (the author of the so called Third Way doctrine that unsuccessfully attempted to invent a palatable version of capitalism). Their answer is that

the erosion of traditions and normative frameworks has resulted in a situation in which life has shifted from something that is pre-structured and given to something that has become a task for the modern individual... For Giddens "high" or "late" modernity - the current phase of modernization - is characterized by an intensification of uncertainty... This suggests that agency becomes even more necessary, yet at the same time it also becomes increasingly difficult to achieve. ...[U]nder the condition of "liquid modernity", there is a yawning gap between the right of self-assertion and the opportunities for actually controlling "the social settings which render such self-assertion feasible" (Bauman, 2000, p. 38). According to Bauman this is particularly due to the demise of the public sphere... (Bauman, 2000, pp. 133-134)

What remains unspecified in this position is why this kind of erosion happened and what it is all about, in more concrete terms than in the above presentation. For example, what exactly is characteristic of the "post-traditional" society with its "liquid modernity"-such as in terms of specific socioeconomic and political processes involved in these changes? That these processes and conditions have to do with the latestage capitalism, marked by the development of corporatism, laissez-faire economics and globalization, is never mentioned in this description, except for a vague reference to "the demise of the public sphere," as is quite typical of neoliberal approaches that eschew structural and political analysis. This type of discourse, which is focused on the notion of "freedom" to take control of one's life through self-regulation, is a well-known mantra of neoliberalism, indeed one of its staples. It actually diverts attention away from increasing exploitation, hegemony, inequality, and racism entailed by the sociopolitical dynamics of the late-stage, predatory capitalism. These dynamics in fact strip people of their agency and instead, provide only meager options via illusionary mechanisms such as self-control, mindfulness, "positive psychology" and other individualistic pseudo-solutions.

A more politically oriented, non-neutral engagement with these issues would suggest an emphasis on dramatic, even tragic, dynamics and devastating effects of late-stage capitalism on human lives and society. These dynamics include class, racial, and sexual oppression and exploitation, with capitalism failing the common good by diminishing social security, shrinking employment opportunities that could provide living wages and stable jobs, causing the erosion of democracy, channeling world's resources into the power of a privileged few, and leading to the overall demise of societies. This is on top of a devastating immigration crisis that is reaching the scale of a humanitarian catastrophe and, last but certainly not least, an ecological apocalypse. As has been stated again and again by various authors, "the normal concomitant of free markets is not stable democratic government. It is the volatile politics of economic insecurity ... democracy and the free market are competitors rather than partners" (Gray, 1998, p. 213). It is this type of the late-stage predatory capitalism that is in the mode of enforced creation not only of markets but also of the individuals who are now increasingly responsible for their welfare and are "free" from socioeconomic supports and thus, de facto impoverished and insecure (cf. Teo, 2018). Importantly, these are also conditions that led to western capitalist societies becoming increasingly stratified by race and social class, with grave implications especially for non-dominant groups (e.g., Langer-Osuna and Nasir, 2016). As Marx predicted, capitalism is presently creating colossally increasing wealth surrounded by disastrously increasing poverty while aiming at marketization of all of society and all of life, including education, in disregard of equality, well-being, and ultimately its own survival.

These topics are barely addressed by Biesta and Tedder (2007) and instead, they conclude their paper with an optimistic statement that "The approach presented in this paper at least indicates one kind of learning that could support individuals' attempts to achieve agency under such conditions" (p. 147; emphasis added). Rather than politically neutral, this is a clear expression of an ideology of passive adaptation to, and acquiescence with, the status quo-the existing order of things and the world as it "is," under which we are supposed to live without much hope for radical changes. This position de facto obviates the need for a careful consideration of and a staunch resistance to catastrophic effects and expressions of the capitalist status quo. This ideology is ultimately, and at best, about encouraging and supporting merely individual "agency" disconnected from social struggles and collective fights for better conditions of life-a severely curtailed form of agency (if this term is applicable at all) that actually stands for passivity in the face of daunting socioeconomic and political dynamics.

In concluding this discussion, the point to emphasize is that much work remains to be done in order to conceptualize agency more in line not only with the relational-ecological but also, deeply dialectical-and importantly, critical-dialectical, or radical-transformative, that is, politically and ideologically non-neutral-premises. The next section presents steps in this direction though, of course, no final answer is thereby presumed since no such answer is possible for an issue like agency that demands close attention to ever-shifting, and now rapidly unfolding with unprecedented force, political and socioeconomic dynamics.

\section{AGENCY IN THE TRANSFORMATIVE WORLDVIEW}

An alternative approach to agency-one that fully takes relational and ecological insights into account, yet also moves beyond them to include critical and reflexive dimensions related to 
socio-political, historical, ethical, and economic deliberationscan start from the core philosophical premises developed in dialectical Marxism and continued in, among other schools of thought, Vygotsky's cultural-historical theory. The broad assumption from this foundation that can be usefully applied to the discussion of agency is that, according to Marx (e.g., Marx, 1978; cf. Marx and Engels, 1978), the social ways through which people collectively act on the world to produce their communal lives constitute a fundamental, determining foundation for all forms of their knowing, being, and doing. Thus, humans are a self-creating species, producing their actual life and society through activities and practices of collective praxis/labor. This notion of transformative collaborative practice (praxis) was advanced in Marxism and taken up in Vygotsky's school (though not consistently elaborated in any sufficient detail) against the naturalistic understanding that only nature affects human beings and that only natural conditions determine their historical development (for details, see Stetsenko, 2016, 2018a).

In further developing this approach within a transformative worldview and onto-epistemology (see Stetsenko, 2013a,b, 2014, 2016; for applications, see Vianna and Stetsenko, 2011; Vianna et al., 2014; Stetsenko and Ho, 2015; Stetsenko, 2017), what is placed at the center stage is a unified process of people collaboratively transforming circumstances of their life and, simultaneously, in this very process, of people being themselves transformed and brought into realization by their own transformative practices. This position puts emphasis on a complex relational and dynamic network of continuous processes of material sociohistorical practices as the nexus of people purposefully changing their world while simultaneously being changed by and in this very process of their own transformational practices. This dynamic, shifting nexus of circular transformative effects is posited as a primary, specifically human relation to the world (which is more than just a neutral relation) - their mode of existence and way of being/becoming.

This move highlights the centrality of agency within a recursive, ever-expanding, dialectical, and transformative coconstitution of both, at once, reality and ourselves that never ends and never leaves anything in place. This process of coconstitution, as a form of meeting the world half-way, in-between ourselves and reality that encompasses both poles, is always on the cusp between what is and what can be, what already exists and what is just now emerging-on the cusp of novelty and creating of what-is-not-yet. In this approach, nothing is settled and set in place, nothing can be taken for granted and presumed to stay still, as somehow already "given," such as the present status quo in our societies. Instead, there are ongoing transformations and transmutations, recursive transitions and back-and-forth interpenetrations-a co-mingling in which everything happens in the meeting, or encounter, of persons and the world that is always transformative of both sides since they are entangled in the flow of mutually co-constitutive and co-realizing changes.

That is, the important nuance of this position is that people are changed neither by the world per se, nor even by the world as it has been changed by them (as is presumed in many traditional accounts of Marx and Vygotsky). Rather, the emphasis is on people being transformed, and de facto realized, in and through this process of them themselves changing the circumstances of their life and their world. People and their world are understood to be coextensive, co-evolving, interanimated, and interdefinable (co-realizing each other) through the nexus of collective practices' transformations and as based in the material reality (the "fabric") of these practices. Here we are dealing not with the reality of what is given but instead, of what is taken by us-that is, how we engage, con-front and en-counter reality-while co-creating, coauthoring and thus co-realizing it with others. The "givenness" of reality (matter) is thus superseded within purposive human activities made up of the ever-changing dynamics of human ongoing transformative efforts and struggles imbued with goals, commitments, and stands.

The social collaborative practices and human development (the two being actually inseparable) unfold within collective dynamics at the nexus of people and the world and as situated in contexts, that is, in some limited sense, "under" given circumstances, albeit importantly, only in transcending these circumstances and while creating new contexts and new circumstances. Therefore, the very status of these circumstances, and thus of the world itself, as something that is "given," is resolutely contested. There are no contexts and circumstances as such, just laying "out there," independently of us and affecting us so that we can only react to their effects after the fact. Instead, these contexts and circumstances are understood to be brought into realization by people in the acts of their own transformative agency (always collective and individual at once) and thus, in the acts of their own self-realization. This realization is co-productive of society, history, human development, and the very fabric of human lives-extending through and connecting all generations within the dynamic flow of collective and communal practices.

A person's actions, and even "mere" presence in the world (which is actually never mere), through them contributing to social collaborative practices, as they always do, inevitably create new situations by changing the totality of existing circumstances in which this person, as well as all others, from now on, have to and can act in new ways-to thus again change these circumstances and conditions in a continuous circuit of ceaseless transformations that constitute the very texture of the process at the intersection of the world and human beings. Therefore, human actions have more direct and more enduring presence than any putatively sturdier, somehow more material and more tangible, things that in fact inevitably always vanish and "melt in the air." It is the practices and activities, composed of human deeds that transform the world that are actually really real (to use Rom Harrés expression) because they are the most consequential phenomena of all-comprising no less than "the fabric" of human reality, society, and development.

For a contrast with the position advocated by Biesta and colleagues, the following premise needs to be emphasized. If we understand ourselves as shaping our responses to problematic situations, then we already, by virtue of this formulation, are taking these situations as "givens," as something that exists independently from and prior to us, for us to merely face them, as they "are," and only consequently tailor our responses to these situations after they have been presented to us and have 
made an impact upon us. The alternative is to see that not only it is not that we simply "are in the world" and always in the process of answering its problems, tasks, and challengesas follows from many presently influential relational-ecological paradigms such as Biesta's. Without completely dispelling this connotation, a critical point that can be made in advancing the relational paradigm beyond its current limitations is that we are not simply "in" the world responding to it, by whatever means at our disposal, as if the world was "out there," outside of us and facing us as something prior to our very being and acting.

The alternative is to understand that we are fully integrated into the world as its essential and indispensable "layers" or "energies"-that is, not in a mechanical sense of some independent and separate elements (entities) being put together (assembled or aggregated) by outside forces into some sort of a larger system. The alternative is about understanding ourselves as agentive co-creators of the world, with the latter being constantly and continuously in the making - and not just in any making, as something that is dynamic and changing by itself, but in the making-by-us-ourselves. This is about understanding ourselves as active from the start, through and through, as endowed with an inalienable agency (albeit always in the process of development) that is nonetheless fully of this world, grounded in the very basis of our existence and entailed in the very mode of our living. In this view, agency is foregrounded as formative and constitutive of human life and development, and in a recursive mode, formative and constitutive of the world itself. There is an important distinction in saying that we encounter the world halfway (as in "meeting the universe half-way," see Barad, 2007), at the intersection of the world and ourselves, vs. saying that we act under given conditions and respond to somehow preexisting problems and challenges. In this way, the still powerful spell of behaviorism and associated adaptive-relational modes of thinking, according to which humans merely dwell in the world and respond to (or follow with) its dictates, under its pre-given conditions, are resolutely debunked.

In this emphasis, the TAS suggests that human beings are not antecedent to communal transformative practices that shape them (a premise that is shared with many sociocultural and critical approaches); however, in a move that breaks with the orthodox notions of canonical Marxism (and many sociocultural and relational approaches), the world is posited as not antecedent to these practices either, as if reality was simply "out there," predefined, and definitively organized before people enact and carry it out in their own activist pursuits, struggles, and strivings and thus bring it, and simultaneously themselves, into co-realization.

In this approach, to summarize, agency is conceptualized as a situated and collectively formed ability of people, qua agents of social practices, history, and the world itself-each person as fully a community member who at the same time is acting from a unique position and stance on a given community's predicaments and conflicts-to co-realize the world and themselves while challenging the existing status quo and contributing to social practices of humanity with a particular horizons of possibilities in sight. Importantly, this ability is contingent on the mastery of cultural tools for transformative action and activism through participating in and contributing to the inherently social, collective processes and practices of human communities.

From the position of the transformative activist stance (TAS), persons are agents not only for whom "things matter" but also who themselves matter in history, culture, and society and, moreover, who come into being as unique individuals through their activist deeds, that is, through and to the extent that they take a stand on matters of social significance and commit to making a difference by contributing to changes in the ongoing social practices. This means that there is no way that we can extract ourselves out of this activist engagement-we can never take a neutral stance of disinterested observers uninvolved in what is going on. A human being who in order to be needs to act in the social world that is constantly changing and, moreover, that is changing through our own deeds, cannot be neutral or uncertain because such acting (unlike reacting or passively dwelling) presupposes knowing what is right or wrong, and which direction one wants and needs to go next, for the benefit of oneself and community practices.

In this sense, agency is an inalienable feature of human knowing-being-doing-though it is not a "given" and instead, it has to do with the socially transformative, practically productive, and collaboratively inventive ways of how human life is organized within the sociohistorical dynamics of human communities. Thus, agency is foundational to human life yet, nonetheless, it has to develop as we develop our capacities for participation in and contribution to community life with the help of collectively invented cultural tools suited for agentive knowing-being-doing. In this account, there is a conceptual space to acknowledge diverse forms of agency and multiplicity of its expressions, contra those approaches that grant agency to only some of its manifestations, specifically the ones that are efficacious within the status quo (as typically described in self-efficacy research, e.g., achieving specific results such social status, solving problems for specific gains or profits etc.) and which require being noticed, approved, and ultimately sanctioned by society and its power holders.

Indeed, forms of agency do not need to be painted with the same brush and it makes sense to take a heterogenous approach to conceptualizing it (cf. Bierria, 2014), including in order to highlight important dimensions of agency and their varying roles in human lives and social dynamics. One scale on which forms of agency can be usefully distinguished, in taking up from Bierria (2014), is that of its insurgent vs. hegemonic modalities. These modalities of agency are situated at the opposite poles defined by social positioning of agents who exercise agency relative to the structures of power and domination. On one pole is a hegemonic agency-the term suggested by Bierria (2014)which typifies exercise of agency by those in power, with a privileged status in society. In case of hegemonic agency (to expand upon Bierria's account), people operate in the interests of the status quo and thus, often act agentively to capitalize on their privileges and status while thwarting or subverting social change and the agency of others, especially those who are marginalized and oppressed. These are not exclusively acts of direct oppression, though this is clearly the most outrageous, 
and quite common, form of hegemonic agency today since domination and oppression are prevalent and paramount in our society, constituting daily realities for disenfranchised people, especially people of color, such as in police brutality and workplace discrimination. Yet even "common" acts of daily misrecognition, mislabeling, and misperception of those who are disenfranchised including ethnic minorities, immigrants, and the poor-by ordinary community members who are privileged by color, class or social status, or are in a position of power within particular contexts such as teachers in their classrooms-can also be seen as a hegemonic agency (without claiming equivalency across gradations within this agency). Examples of such agency include teachers' differential treatment of learners based in racial stereotypes (which is quite common, see Tenenbaum and Ruck, 2007), including prejudicial mislabeling of students as incapable of learning based on achievement testing that is inherently biased and fundamentally inadequate to capture anything meaningful about students' potential for learning. Moreover, I believe that the utterly common, everyday actions by the privileged who follow with the normativity and rules of established societal canons-such as being "at peace" with inequalities, discrimination, and oppression and not challenging them-can also be considered to belong to hegemonic agency. This includes, as regards educational settings such as academia, channeling, rather than resisting, "dominant ideologies and representations that normalize/rationalize war, state violence, White supremacy, capitalism, and injustice, even and especially within the psychological canon" (Fine, 2018, p. 431).

On the other pole of agency modalities is an insurgent agency-again, the term introduced by Bierria (2014) and powerfully illustrated in her work. As she writes, insurgent agency pertains to

resistant acts employed by disenfranchised agents that are not necessarily designed to transform or transcend oppression, but instead manipulate and maneuver those conditions to achieve ends that are structured as unachievable. These acts have the potential to corrode elements of structural domination while still operating within the violent constraints of power... [Insurgent agency] temporarily destabilizes, circumnavigates, or manipulates those conditions in order to reach specific ends. (Bierria, 2014, p. 140)

What the term radical-transformative agency highlights in addition, as I suggest, is that the ultimate forms of insurgent agency are specifically about overcoming accommodation of, or adaptation and acquiescence to, the existing status quo of a neoliberal political framework with its power imbalances, exploitation, oppression, and violence. Radical-transformative agency is not about being able to effect changes that are only narrowly efficient for the goals of taking control of one's life, achieving success and other self-serving, egotistic pursuits centered on individuals, each on their own, fitting in with the present regime of neoliberalism. In other words, this type of agency is not about efficacy and efficiency of individuals taken as autonomous entities. Instead, radical-transformative agency is about struggles against inequality, economic oppression, racism, and other forms of injustices as these are operating within local communities, including schools, yet also as they inevitably form parts of the overall historically and politically contingent dynamics, in connection to larger contexts of the world-historical struggle. This world-historical struggle, in its present expressions and enactments (as I see it, in sync with many critical scholars) is primarily and centrally against the neoliberalcapitalist socioeconomic and political regime which today is the central challenge and the main historically and politically contingent force that needs to be resisted and struggled against.

Thus, the critical point is that the radical-transformative agency takes place as a confrontation with the status quo in its presently dominant (and always historically particular) major contradictions, injustices, and shortfalls that happen to define this status quo at a given historical time and place. These contradictions, injustices, and shortfalls need to be distilled, identified, named, and faced head-on by teachers and students alike, as part of their struggle for a better world coterminous with their own becoming-their becoming agents of history and of the world-in-the-making.

As is clear from the ongoing discussion, the radicaltransformative agency is likely to be carried out by those who are "marginalized, made illegible and spoken-over by the contemporary geopolitics of capitalist coloniality" (to borrow from Motta and Esteves, 2014, p. 1), whereas enfranchised agents who are "shareholders" of the social and institutional power (Bierria, 2014), especially at the higher echelons of power, are likely to resist it (though some might potentially join the struggle). This type, or modality, of agency does not always fully depend on explicit social affirmation, or an immediate social uptake, and is not necessarily contingent on its effects in terms of a directly "measurable" impact on the world-as argued also by Bierria (2014) in her astute analysis of various agency modalities. As Bierria suggests, "there is a key social dimension to agency that is vulnerable to being corrupted by oppression" (p. 135), such as when there is no social uptake and validation of actions and their effects out in the world. Bierria, in addition, suggests that the disenfranchised actors might be able to achieve agency with the backup of an alternative public, such as social movements. I would add to this account that the actions of disenfranchised often de facto challenge the status quo and thus, serve as radical and insurgent forms of agency that subvert oppressive powers. This happens, for example, when students drop out of school, effectively undermining the workings of the educational system, as if shedding light (often at a great cost to themselves) on how dysfunctional and oppressive this system actually is (cf. Fine, 1991). There are numerous examples of research that highlight "moment-to-moment opportunities as a form of day-to-day activism," such as teaching for raising consciousness, in a struggle to change whitestream urban schools as a part of being a Chicana/o Activist (Urrieta, 2007); supporting students' agency within "cracks and crawl spaces in existing social structures" (Carlone et al., 2015), and documenting how agency can accrue over time, as small events serving to be playhouses for larger social forces that disrupt oppression in the classroom (Varelas et al., 2015; cf. Gutiérrez and Calabrese Barton, 2015). 


\section{RADICAL-TRANSFORMATIVE AGENCY: IMPLICATIONS FOR TEACHING-LEARNING}

The proposal in this paper is to focus on the process of people transformatively engaging and thus co-realizing the world-inthe-making and themselves through unique-though always co-coordinated, social, and collective through and throughcontributions to this world's dynamic and ever-changing interactivity. This process is posited at the core of human development, societal processes and the world materiality itself, as suggested herein in line with an expanded Marxist-Vygotskian approach. By implication, this same process can be posited also at the core of teaching-learning processes understood as intrinsic to the world's overall dynamics. This is because these processes cannot be thought of as somehow self-standing and withdrawn from the world and its overall dynamics and interactivities. Schools are direct mirrors of our society-a living embodiment of its dynamics in all of its strengths and weaknesses, including most critically its inequalities and injustices. Indeed, as has been noted before, there are only fluid boundaries or a "flux of boundaries" (cf. Greene, 1974) between schools and societies. That is, because teaching-learning is an immediate and inherent part of the overall dynamics and processes of human life and society, its core determinations are not distinct from these overall dynamics. If we look closely enough, with relevant conceptualanalytical tools, we might see both the social-political dynamics and those of the human being/becoming in every act of teachinglearning, including every classroom interaction and every aspect of schooling.

In this light, the teaching-learning process-like all processes of social and human dynamics-is about the teachers' and learners' struggle for becoming (always collective and individual at once, that is, "collectividual," see Stetsenko, 2013a), for mattering, through transformatively engaging the world via unique and authorial contributions to its ever-changing dynamics. This is about strivings and struggles for an agentive participation in and, most critically, contribution to community practices, and thus to the world-in-the-making of a profoundly activist nature. As such, teaching-learning is an arena of human struggle and activist striving that is immanently and inherently infused, at its core, with ethics and politics on the one hand, and with emotions, passions, feeling, values, fears, pain, hopes, and interests-on the other (cf. Stetsenko, 2010, 2016).

This position implies that teaching-learning always needs to connect to, and be grounded within, the process of learners and teachers developing their own projects of participating and mattering in community practices, via envisioning their possible futures and their selves to be a certain way, making commitments to this way, and working on bringing these commitments into realization. Each act of teaching-learning, in this light, is a complex, contested, and non-neutral endeavor loaded with human significance and personal meaning, including dimensions such as emotions and passions. In this endeavor, much is at stake and it itself is at stake in many ways and in many aspects of life well-beyond the immediate context within the classroom walls. The teachers' and learners' goals and strivings toward the future, how they imagine the horizon of possibilities and what they struggle for, in fact color and shape the teaching-learning dynamics in the present. While being deeply personal, these processes are not about some idiosyncratic, personalized quests confined to isolated individuals and defined in terms of putatively solo dynamics separated from the larger world. Instead, teachinglearning and knowing are inextricably parts and parcels in the dynamic processes of an active and agentive, indeed activist, striving for one's authenticity, co-authorship, and place in the shared world of communal practices.

Although acknowledging the value of all participants in the teaching-learning process developing their own, unique ways of contributing to community practices, this process is at the same time and ultimately always about developing "a shared consciousness of oppression, leading to a shared sense of knowledge, and a shared commitment to... finding [a] path to liberation" (Jackson, 1997, p. 464). Note that the notion of individually unique contribution to collectivecommunal practices overcomes the outdated separation of and the harmful rift between individual and social dimensions of sociocultural dynamics.

From this position, agency is paramount to teaching-learning if the latter is understood to be about meaningful, active, and passionate knowing-being-doing by people as actors of history and agents of the world-in-the-making. There is no place in this process for passive transmission of knowledge, faithful memorization to the test, dispassionate information processing, "neutral" data crunching, and other types of purely cognitive and essentially neutral, and thus a-personal and a-meaningful, activities. As has been stated by many scholars, teaching-learning entails developing social identities associated with community practices and discourses (Lave and Wenger, 1991). In pushing this thinking further, I suggest we need to consider that in order to teach and learn in meaningful and lasting ways, we need to draw connections to pursuits of meaningful and activist goals, agendas, and projects grounded in visions and imaginations of a sought-after future that, in case of radicaltransformative agency, presuppose challenging and changing the status quo. It is these pursuits and activist struggles that come to enact teaching-learning in profoundly meaningful and deeply personal and, therefore, lasting and socially significant ways; they are the overarching process within which meaningful and transformative teaching-learning is uniquely possible. The cornerstone of teaching-learning, in other words, is formed by a commitment to social transformation that uniquely positions learners-and teachers alike-to see what is through the prism of how present situations and conditions came to be and, also, in light of the imagined and sought-after future-of what they believe ought to be. In this, the historicity and situativity of knowledge are ascertained alongside the focus on its ineluctable fusion with an activist stance as an orientation toward the future.

In this approach, teaching-learning, being embedded in and derivative of social practices and struggles of becoming, is most critically premised on and constituted by activities not merely in the "here and now," in the world and its circumstances as 
if they were somehow simply "given" (which in fact they never are). Instead, teaching-learning intersects with the future and foregrounds imagination, daring, and movement beyond the status quo. Imagining a different world and ourselves, making a commitment to bringing these about and struggling to achieve them amounts to creating the future in the present-affirming the future-to-come and thus realizing it in the here and now. This is the process of inventing the future, rather than merely expecting or anticipating its "automatic" arrival.

The critical constituent of teaching-learning (and all forms of knowing-being-doing), therefore, is about taking stands and staking claims on ongoing events in view of the purposes, goals, commitments, and aspirations for the future. In this sense, the common expression "make up your mind," which typically is taken as an appeal to form an opinion or a point of view in addition to the ongoing cognitive (supposedly disinterested, neutral) processes, can be interpreted instead as a general stipulation that the mind develops while we quite literally make it up. That is, rather than merely "having" (or possessing) minds, we are always in the process of making them up-because the minds are literally "made" in the collaborative practices and pursuits, and also because they are formed and enacted in the process and as the process of taking activist positions and stands. Taking up and carrying out activist stands are truly vital in order to be able to act, to be, and to know-to under-stand. The immediate implication for the process of teaching-learning is that its goal has to do with assisting students in developing their ability to take their own stands and stake their own claims on what is going on in the world and their communities, including their place and role in these processes, while learning to matter, that is, imagine and commit to a future they come to believe is worthy a struggle.

The emphasis on social change and people transcending the status quo through their agentive contributions to social practices implies agency/activism, in the connotation of imagination, novelty and creativity, as the core characteristics of human beingknowing-doing (see Stetsenko, 2019a). This is about bringing new and expansive anti-oppressive practices-such as critical reflection on and citizen participation in communal practices and civic activities, including resistance, social activism, and community-oriented decision making-directly into schooling while enmeshing them with academic matters in the process of teaching-learning.

One example of this strategy can be found in the study of teaching-learning with adolescent boys in a group home (part of the American foster care system; for details on this project, see Vianna, 2009; see also Vianna and Stetsenko, 2011, 2014, 2019). One of the strategies employed in this work was to invite participants to explore the ethical-political dimensions of knowledge in connection with the boys' own thematic universe, thus compelling them to take a stand on social and academic issues in their own lives, their communities, and the society at large. One of the topics for an extended discussion was that of human evolution. This topic was chosen as an opportunity to critically examine erroneous assumptions associated with a reductionist version of evolutionary theory that promotes the fallacious and racist, and quite widespread, view that race-based social inequality is biologically determined (cf. Stetsenko, 2011,
2017, 2018b; Vianna and Stetsenko, 2017). This was a view that some of the boys articulated, apparently taken up from social discourses and practices in their surrounds.

A workshop on evolution, led by Eduardo Vianna as part of a collaborative transformative project that he carried out in the group home (in collaboration with the present author), provided a forum for the boys to discuss their views on such contentious matters as social ranking and presumed inequalities in human potential while confronting outrageous stereotypes about so called "Black inferiority," and whether notions of evolution support or challenge such views. Importantly, students were invited to take a position, or active stance, on the conundrums involved, including by interrogating their own views and possible biases. The strategy was not about imposing some "finalized" knowledge claims as canons that could not be contested. Quite on the contrary, learners were provided with the critical-theoretical tools to explore knowledge and its underlying ethical-political premises and implications so that they themselves could stake a claim and claim a position, however preliminary and evolving, on the key conundrums involved. One of such tools was knowledge that all theories and concepts carry with them specific (typically deeply-seated) ethico-political bases, biases, and implications (see Stetsenko, 2015, 2018a,b). As described in Vianna and Stetsenko (2019), aided by critical-theoretical tools of agency, the boys' views on race relations and institutional practices as intractable and fixed gave way to a desire to better analyze such practices in order to transform them. As the boys developed their activist transformative stance, drastic changes in themselves and their institution started to unfold. These new understandings spurred the boys' commitment to fight racial stereotypes and change their community practices along the lines of solidarity and social justice-with such changes indeed ensuing soon thereafter, with dramatic positive results at both personal and community levels in the institution.

As relates to combatting inequality in education, one important part of achieving this goal, from the position outlined herein, is overcoming the notions of passivity including that of teachers as "conduits of knowledge." An indispensable ingredient for combatting inequality, racism and quietism in our schools has to do with creating spaces where both teachers and learners can rid themselves of expectations to comply with the status quo (in both knowledge and community participation) to instead launch on their own paths and projects of critical explorations into the world and themselves, while committing to their own visions of the future and to finding their own answers as to how to achieve this future. This is about providing conditions and spaces for teachers' and learners' rousing to life their own activist projects and radical-transformative agency, for daring to change the world for the better. Such an approach is not about indoctrination. Instead, it is about teachers and learners together engaging big, complex questions about ourselves and our society including about inequality, social justice, and our role in the world. Such questions include interrogations of, as Gause et al. (2009, p. 49) put it drawing on Anzaldúa and Macy, "What are the tacit agreements that create obscene wealth for a few, while progressively impoverishing the rest of humanity? and What interlocking systems of power causes indenture to us 
while simultaneously creating an economy that uses the Earth as house and sewer?" At stake, in other words, is education that is about teachers and learners carrying out the hard work to assert themselves in the actualization of their own potential via mattering in the world shared with others.

\section{INSTEAD OF CONCLUSIONS: SOCIOPOLITICAL IMPLICATIONS}

The account of radical-transformative agency-premised on the notion of individuals seeking to make contributions to communal practices based in their own commitments to a better future, in challenging and moving beyond the status quo (as conceptualized herein) - is not a universal, timeless proposal that could be set in place and taken for granted "for all times." In fact, it itself is tightly bound up with the present realities of our historical time and place, highly conflictual, turbulent, and in need of radical and even disruptive-insurgent, forms of agency. In my view, researchers' commitments to how these realities can be co-authored and realized by us today (per my interpretation, as relates to the need to combat stark inequalities and injustices of the late-stage capitalism and this system itself) is an important part of theorizing agency. This proposal strives to be congruent with the transformative and revolutionary, indeed rebellious, gist of Vygotsky's project as it initially emerged during the time of the anti-capitalist revolution, even though this gist was not directly articulated by this project's originators (and unfortunately, gradually squashed with the advancing totalitarianism).

Today, in an era of global social strife and record inequality, which concentrates ever-growing wealth and power in the hands of a corrupt ruling class, accompanied by a bleeding immigration crisis and ecological disaster, it is obvious that capitalism is gradually disintegrating into chaos and wars that are wreaking havoc around the globe. Therefore, it is time for an activist and radical-transformative scholarship, especially on the topic of agency, premised on commitments to a chosen socio-political ethos-as argued herein, that of a fundamental equality, solidarity, and infinite potential of all human beings that can all be achieved only in a post-capitalist society. In Kohn (2015) words, "we need to be transparent about our premises and goals [including, centrally, the political ones]. If we don't bring them to the surface and defend them, others will take their place by default" (insert added). As Kohn continues, "show me a school where people blithely announce they do 'whatever works' and I'll show you a place tacitly defined by behaviorism...". Paraphrasing Kohn, I would say-show me a conception of agency that operates with the notion of responding to the world and stays away from

\section{REFERENCES}

Barad, K. (2007). Meeting the Universe Halfway: Quantum Physics and the Entanglement of Matter and Meaning. Durham, NC: Duke University Press.

Bauman, Z. (2000) Liquid Modernity. Cambridge: Polity Press.

Bierria, A. (2014). Missing in action: violence, power, and discerning agency. Hypatia 29, 129-145. doi: 10.1111/hypa.12074

Biesta, G., Priestley, M., and Robinson, S. (2015). The role of beliefs in teacher agency. Teach. Teach. 21, 624-640. doi: 10.1080/13540602.2015.1044325 politics, and I will show you a conceptual terrain tacitly defined by behaviorism and neoliberalism.

As educators and researchers of agency, we need to "dance the dance" and be ourselves agentive in our scholarly pursuits of theorizing and exploring agency. Unless we define our quest for a better future (at least in outlines as attempted herein) and situate our research within such a quest, as part and parcel in the struggle against the status quo defined in concrete political terms, we remain under the spell of behaviorism and other approaches steeped in colonial and racist legacy. The goal, in my view, is to resolutely break with the tacit legitimation of the status quo by these approaches, whereby agency is limited to being just a response which is accommodating what is erroneously perceived as an unalterable, immutable status quo. In further pursuing this approach, the need is to connect to the rich tradition of critical theories of resistance and oppositional consciousnesssuch as Critical Race theories, decolonial approaches, and Liberation philosophy, in the spirit of alliance-building strategies for globalizing resistance from below, as put by Davis (2000). The strategy includes connecting to classical works of not only Marx and Vygotsky but also W. E. B. Du Bois, Frantz Fanon, and to contemporary works by Gloria Anzaldúa, Chela Sandoval, Audre Lorde, and Angela Davis, among many others.

In conclusion I would like to use Angela Davis' words addressed to the readers of Chela Sandoval's book Methodology of the Oppressed (Davis, 2000). As Davis writes (pp. xii-xiii), the book is about "understanding how to effect dissidence within twenty-first century cultural conditions" so as to work toward "creating a place for significant interventions in the social world... as a prolegomenon that critically examines the conditions and possibilities for contemporary radical movements in this era of global capitalism.” To this I am humbly adding, in solidarizing with this line of work, that effecting dissidence (including in challenging canons of passivity and behaviorism in psychology and education) de facto also means going beyond our present conditions in creating radical possibilities for social transformation. Indeed, we need all the resources for a solidaristic, radical-transformative agency, including those furnished by activist theories of agency, to push forward in moving past the established canons and social structures that only appear to be intransigent while in fact they are already melting in the air in front of our eyes.

\section{AUTHOR CONTRIBUTIONS}

The author confirms being the sole contributor of this work and has approved it for publication.

Biesta, G. J. J., and Tedder, M. (2006). How is Agency Possible? Towards an Ecological Understanding of Agency-as-Achievement. Working paper 5. Exeter: The Learning Lives project. Available online at: https://www.researchgate.net/ profile/Michael_Tedder/publication/228644383_How_is_agency_possible_ Towards_an_ecological_understanding_of_agency-as-achievement/links/ 00b4952cadd9bd2b6a000000.pdf (accessed July 15, 2019).

Biesta, G. J. J., and Tedder, M. (2007). Agency and learning in the lifecourse: towards an ecological perspective. Stud. Educ. Adults 39, 132-149. doi: 10.1080/02660830.2007.11661545 
Carlone, H., Johnson, A., and Scott, C. (2015). Agency amidst formidable structures: how girls perform gender in science class. J. Res. Sci. Teach. 52, 474-488. doi: 10.1002/tea.21224

Davis, A. Y. (2000). "Foreword," in Methodology of the Oppressed, ed C. Sandoval (Minneapolis: University of Minnesota), xi-xiii.

Edwards, A. (2005). Relational agency: learning to be a resourceful practitioner. Int. J. Educ. Res. 43, 168-182. doi: 10.1016/j.ijer.2006.06.010

Emirbayer, M., and Mische, A. (1998). What is agency? American Journal of Sociology, 103, 962-1023. doi: 10.1086/231294

Eteläpelto, A., Vähäsantanen, K., Hökk, Ä. P., and Paloniemi, S. (2013). What is agency? Conceptualizing professional agency at work. Educ. Res. Rev. 10, 45-65. doi: 10.1016/j.edurev.2013.05.001

Fine, M. (1991). Framing Dropouts: Notes on the Politics of an Urban High School. Albany, NY: State University of New York.

Fine, M. (2018). "Bear left: the critical psychology project in revolting times," in The Oxford Handbook of Social Psychology and Social Justice, ed P. L. Hammack (New York, NY: Oxford University), 429-440. doi: 10.1093/oxfordhb/9780199938735. 013.33

Gause, C. P., Okun, T., Stalnaker, A., Nix-Stevenson, D., and Chapman, D. (2009). The counterstory and the promise of collaborative compassion in education. Learn. Democr. 3, 42-51.

Gray, J. (1998). False Dawn: The Delusions of Global Capitalism. New York, NY: The New Press.

Greene, M. (1974). Teacher as Stranger: Educational Philosophy for the Modern Age. Belmont, CA: Wadsworth.

Gutiérrez, K., and Calabrese Barton, A. (2015). The possibilities and limits of the structure-agency dialectic in advancing science for all. J. Res. Sci. Teach. 52, 574-583. doi: 10.1002/tea.21229

Hull, C. L. (1943). Principles of Behavior. New York, NY: Appleton-Century-Crofts.

Jackson, S. (1997). Crossing borders and changing pedagogies: from Giroux and Freire to feminist theories of education. Gend. Educ. 9, 457-468. doi: $10.1080 / 09540259721196$

Kohn, A. (2015). "To change what we do, consider what we believe. Foreword," in The Teacher You Want to be: Essays About Children, Learning, and Teaching, eds M. Glover and E. Keene (Portsmouth, NH: Heinemann). Available online at: https:/www.psychologytoday.com/us/blog/the-homework-myth/201510/ change-what-we-do-consider-what-we-believe (accessed July 15, 2019).

Kumpulainen, K., Kajamaa, A., and Rajala, A. (2018). Understanding educational change: agency-structure dynamics in a novel design and making environment. Dig. Educ. Rev. 33, 26-38. doi: 10.1344/der.2018.33.26-38

Langer-Osuna, J. M., and Nasir, N. S. (2016). Rehumanizing the "other": race, culture, and identity in education research. Rev. Res. Educ. 40, 723-743. doi: 10.3102/0091732X16676468

Lave, J., and Wenger, E. (1991). Situated Learning: Legitimate Peripheral Participation. New York, NY: Cambridge University.

Marx, K. (1978). in Economic and Philosophical Manuscripts, 2nd Edn. eds R. C. Tucker and Marx/Engels reader (New York, NY: Norton), 66-125.

Marx, K., and Engels, F. (1978). in The German Ideology, 2nd Edn. ed R. C. Tucker and Marx/Engels reader (New York, NY: Norton), $146-200$

Motta, S. C., and Esteves, A. M. (2014). Reinventing emancipation in the 21st century: the pedagogical practices of social movements. Interface 6, 1-24.

Priestley, M., Biesta, G. J. J., and Robinson, S. (2015). Teacher Agency: An Ecological Approach. London: Bloomsbury.

Sannino, A., Engeström, Y., and Lemos, M. (2016). Formative interventions for expansive learning and transformative agency. J. Learn. Sci. 25, 599-633. doi: 10.1080/10508406.2016.1204547

Sawyer, K. (2007). "Introduction: the new science of learning," in The Cambridge Handbook of the Learning Sciences, ed K. Sawyer (Cambridge: Cambridge University Press), 1-18.

Stetsenko, A. (1999). "Social interaction, cultural tools, and the zone of proximal development: in search of a synthesis," in Activity Theory and Social Practice, eds M. Hedegaard, S. Chaiklin, S. Boedker, and U. J. Jensen (Aarhus: Aarhus University Press), 235-253.

Stetsenko, A. (2005). Activity as object-related: Resolving the dichotomy of individual and collective types of activity. Mind Culture Activity 12, 70-88. doi: 10.1207/s15327884mca1201_6
Stetsenko, A. (2008). From relational ontology to transformative activist stance: expanding Vygotsky's (CHAT) project. Cult. Stud. Sci. Educ. 3, 465-485. doi: $10.1007 /$ s11422-008-9111-3

Stetsenko, A. (2010). Teaching-learning and development as activist projects of historical becoming: expanding Vygotsky's approach to pedagogy. Pedagogies 5, 6-16. doi: 10.1080/15544800903406266

Stetsenko, A. (2011). "Darwin and Vygotsky on development: an exegesis on human nature," in Children, Culture and Education, eds M. Kontopodis, Ch. Wulf, and B. Fichtner (New York, NY: Springer), 25-41.

Stetsenko, A. (2012). Personhood: an activist project of historical becoming through collaborative pursuits of social transformation. New Ideas Psychol. 30, 144-153. doi: 10.1016/j.newideapsych.2009.11.008

Stetsenko, A. (2013a). The challenge of individuality in cultural-historical activity theory: "Collectividual" dialectics from a transformative activist stance. Outlines Crit. Pract. Stud.14, 7-28.

Stetsenko, A. (2013b). "Theorizing personhood for the world in transition and change: Reflections from a transformative activist stance," in The Psychology of Personhood: Philosophical, Historical, Social-Developmental, and Narrative Perspectives, eds J. Martin and M. H. Bickhard (New York City, NY: Cambridge University), 181-203. doi: 10.1017/CBO9781139086493.013

Stetsenko, A. (2014). "Transformative activist stance for education: Inventing the future in moving beyond the status quo," in Psychology in Education: Critical Theory Practice, ed T. Corcoran (Rotterdam: Sense), 181-198. doi: 10.1007/978-94-6209-566-3_12

Stetsenko, A. (2015). "Theory for and as social practice of realizing the future: Implications from a transformative activist stance," in The Wiley Handbook of Theoretical and Philosophical Psychology: Methods, Approaches, and New Directions for Social Sciences, eds J. Martin, J. Sugarman, and K. Slaney (New York, NY: Wiley), 102-116. doi: 10.1002/9781118748213.ch7

Stetsenko, A. (2016). The Transformative Mind: Expanding Vygotsky's Approach to Development and Education. New York, NY: Cambridge University. doi: $10.1017 / 9780511843044$

Stetsenko, A. (2017). Putting the radical notion of equality in the service of disrupting inequality in education: research findings and conceptual advances on the infinity of human potential. Rev. Res. Educ. 41, 112-135. doi: 10.3102/0091732X16687524

Stetsenko, A. (2018a). Research and activist projects of resistance: the ethicalpolitical foundations for a transformative ethico-onto-epistemology. Learn. Cult. Soc. Interact. doi: 10.1016/j.lcsi.2018.04.002. [Epub ahead of print].

Stetsenko, A. (2018b). Confronting biological reductionism from a social justice agenda: transformative agency and activist stance. Liter. Res. 67, 44-63. doi: $10.1177 / 2381336918787531$

Stetsenko, A. (2019a). "Creativity as dissent and resistance: transformative approach premised on social justice agenda," in The Palgrave Handbook of Social Creativity, eds I. Lebuda and V. Glaveanu (London: Springer), 431-446. doi: 10.1007/978-3-319-95498-1_26

Stetsenko, A. (2019b). Hope, political imagination, and agency in Marxism and beyond: Explicating the transformative worldview and ethico-ontoepistemology. Educational Philosophy and Theory, doi: 10.1080/00131857.2019.1654373. [Epub ahead of print].

Stetsenko, A. (in press). "Personhood through the lens of radical-transformative agency," in Introduction to a Humanities Approach to the Psychology of Personhood, eds J. Sugarman and J. Martin (New York, NY; London: Routledge).

Stetsenko, A., and Arievitch, I. (1997). Constructing and deconstructing the self: comparing post-Vygotskian and discourse-based versions of social constructivism. Mind Culture Activity 4, 160-173. doi: $10.1207 / \mathrm{s} 15327884 \mathrm{mca} 0403 \quad 3$

Stetsenko, A., and Arievitch, I. (2004). The self in cultural-historical activity theory: reclaiming the unity of social and individual dimensions of human development. Theory Psychol. 14, 475-503. doi: 10.1177/0959354304044921

Stetsenko, A., and Ho, P.-C. G. (2015). The serious joy and the joyful work of play: children becoming agentive actors in co-authoring themselves and their world through play. Int. J. Early Childhood 47, 221-234. doi: $10.1007 / s 13158-015-0141-1$

Tenenbaum, H. R., and Ruck, M. D. (2007). Are teachers' expectations different for racial minority than for European American students? A meta-analysis. J. Educ. Psychol. 99, 253-273. doi: 10.1037/0022-0663.99.2.253 
Teo, T. (2018). Homo neoliberalus: from personality to forms of subjectivity. Theory Psychol. 28, 581-599. doi: 10.1177/0959354318794899

Urrieta, L. (2007). Identity production in figured worlds: how some Mexican Americans become Chicana/o activist educators. Urban Rev. 39, 117-144. doi: 10.1007/s11256-007-0050-1

Varelas, M., Tucker-Raymond, E., and Richards, K. (2015). A structureagency perspective on young children's engagement in school science: Carlos's performance and narrative. J. Res. Sci. Teach. 52, 516-529. doi: $10.1002 /$ tea.21211

Vianna, E. (2009). Collaborative Transformations in Foster Care: Teaching-Learning as a Developmental Tool in a Residential Program. Saarbrücken: VDM Verlag Dr. Müller.

Vianna, E., Hougaard, N., and Stetsenko, A. (2014). "The dialectics of collective and individual transformation: transformative activist research in a collaborative learning community project," in Collaborative Projects, ed A. Blunden (Leiden: Brille), 59-87.

Vianna, E., and Stetsenko, A. (2011). Connecting learning and identity development through a transformative activist stance: application in adolescent development in a child welfare program. Hum. Dev. 54, 313-338. doi: $10.1159 / 000331484$

Vianna, E., and Stetsenko, A. (2014). "Research with a transformative activist agenda: Creating the future through education for social change," in Learning in and Across Contexts: Reimagining Education, Vol. 113, ed J. Vadeboncoeur (National Society for the Studies of Education Yearbook), 575-602.

Vianna, E., and Stetsenko, A. (2017). "Expanding student agency in the introductory psychology course: transformative activist stance and critical-theoretical pedagogy," in How We Teach Now: The GSTA Guide to Student-Centered Teaching, eds R. Obeid et al. Retrieved from: http:// teachpsych.org/ebooks/ (accessed July 15, 2019).

Vianna, E., and Stetsenko, A. (2019). Turning resistance into passion for knowledge with the tools of agency: teaching-learning about theories of evolution for social justice among foster youth. Perspectiva 37, 864-886. doi: 10.5007/2175-795X.2019.e61082

Conflict of Interest: The author declares that the research was conducted in the absence of any commercial or financial relationships that could be construed as a potential conflict of interest.

Copyright () 2019 Stetsenko. This is an open-access article distributed under the terms of the Creative Commons Attribution License (CC BY). The use, distribution or reproduction in other forums is permitted, provided the original author $(s)$ and the copyright owner(s) are credited and that the original publication in this journal is cited, in accordance with accepted academic practice. No use, distribution or reproduction is permitted which does not comply with these terms. 